\title{
Research on Talents Cultivation of College Students Based on "Market Product Concept" Model
}

\author{
Yan Yongxia \\ Liaoning Mechatronics College \\ Dandong Liaoning, China \\ e-mail: arnold0110@sina.com \\ * Corresponding Author
}

\begin{abstract}
The society need the professional talents who are with good profession skill quality and can adapt quickly to the society. However, the students cultivated by current traditional education can't meet the requirements of the talent market . Considering the quality problem of the student cultivation, set out from the "market product concept " and put forward to cultivating talents according to market demand. By solving the problems of professional pertinence, technical application and pre-job training of the students to achieve the goal of effective transition between the graduation and the employment.
\end{abstract}

Keywords-Higher education; product market concept; talent cultivating mode; quality-oriented education; production mode

\section{INTRODUCTION}

In traditional higher education, the talent shortage and the requirement for degree make the higher education on the top of the social "ivory tower" and the difficult employment problem emerges. The difficult employment problem is ,by no means ,the problem of supply is greater than demand. In fact, enterprises in development need a lot of talents and hunt talents in the market. On the contrary, every year, a large number of graduates struggle to find jobs. The essential reason for this contrary is only one--the quality and applicability of the"product",namely the comprehensive quality of college students.

This template provides authors with most of the formatting specifications needed for preparing electronic versions of their papers. All standard paper components have been specified for three reasons: (1) ease of use when formatting individual papers, (2) automatic compliance to electronic requirements that facilitate the concurrent or later production of electronic products, and (3) conformity of style throughout a conference proceedings. Margins, column widths, line spacing, and type styles are built-in; The formation of college students' comprehensive quality required by market depends on the cultivation concept which meets the era demand. The right cultivation concept is the key to form good comprehensive quality for both teachers and students.Higher education advocates"You can lead a horse to water but you can't make him drink." But the key is how to "guide", what's the method and the direction of "guide". This is related to future market adaptability of the graduates.

\section{RESEARCH BACKGROUND}

According to the statistical analysis on the investigation of 2007 college students' employment situation of the education department, there are nearly $60 \%$ of college graduates facing unemployment. Among them ,due to "lack of social experience" which has become the main factor, $52.14 \%$ of the college students have trouble finding a job.Because of insufficient personal ability, $24.14 \%$ of the students are restricted to employment. Ignore other factors, only these two factors account for $66.28 \%$ of the students who are faced with unemployment due to insufficient experience and ability. Thus, can it be concluded that nearly half of the college graduates don't have the ability market requires? The problem mainly stems from the higher education cultivation process under the restriction of traditional concept. It's a lack of talent market research.The colleges "production" doesn't match the "market", thus they don't produce the "right product "for the market.As a result, the graduates are faced with unemployment dilemma after graduation."Market concept" is to cultivate marketable "talent product". Besides, the cultivation method under"product market"concept will have a win-win result to enterprises, colleges, parents and students. Market requires the college graduates not only have solid skills but also good basic quality. By"market demand", colleges can strengthen the cultivation of students' comprehensive quality, help students to set realistic goals and make them prepared in knowledge and skills for their future work . Meanwhile, colleges can make full use of "market" mechanism, solve the contradiction between supply and demand of talent, make students know corporate culture in advance, get ready to integrate to enterprise as soon as possible and make higher education further develop and deepen in application. Under this concept, the relationship between college and talent market will become close and practical . It will definitely be a challenge for higher education concept sticks for many years.

\section{HIGHER EDUCATION “PRODUCT MARKET” CONCEPT}

\section{A. What's higher education "product market" concept}

Enterprise is to produce marketable products for the society and college is to cultivate required talents for the society. The only difference between the former and the 
latter is the commodity value and talent value. But they have consistency: both the "products" must adapt to the needs of society; and they both need to strengthen the function and the practicability of the"products" ,namely the use value and value.Enterprises create profits by selling the products well and colleges win the education and development(profit) with "good products" shortage. Because of its output similar to the market demand, colleges should learn the advantage of enterprise product market rules to management education.

"Product marketing" concept of the university education is to manage colleges with the marketing concept, cultivate solid theoretical basis depending on colleges, investigate the variation tendency of the talent demand at present and in the future, determine talents type, correctly evaluate the demand and choose the best correct target for talents marketing.Revise the cultivation plan according to the adaption needs and development, arrange teaching, shape the talents needed, meet the needs of target market to the greatest extent. At the same time , actively collecting after-sale "product" feedback information from employer and provide strategic basis for further deepening education of colleges.

Model process of "Product marketing" concept ": market demand survey, foresight, determine the object plan, manufacturing-according-to-sale, cultivate and plan implementation, enterprise application practice, the adjustment cultivation program (perfect), new training plans execution (refined), test in practice, cultivation programs fine-tuning, output talents.

\section{B. The function of higher education "product market" concept}

1) "Product market" education concept has the characteristics of thinking

It's an cultural atmosphere of scientific research and actual education, a teaching spirit, an expectation required by era, theory and practice united with teaching goal. It guides the teaching work in colleges and cultivate creative students. It has an effect of regulating, guiding and cultivating behaviors or both teachers and students to adapt to demand. It strengthens and improves cultivation goal and development direction of college. Set up the value which serves society and enterprise. Colleges can be better united to form education power and teaching spirit with which colleges, students and enterprises are confident.

2) "Product market" education concept is the objective reflection of education practice.

"Product market" education concept strengthens the close connection between education and practice, thus boosts the close connection between theory teaching and practice as well as the theory development and application in practice."Product market" education concept is the objective reflection of education practice. Taking education practice as the condition of cultivating talents and scientific research, it plays the role of mutual promotion and mutual development.

3) "Product market" education concept has the advancement of era development.

With the development of social progress, the talents demand of the society has been changed greatly. Higher education no longer "according to templates " cultivates "mechanical" graduates under the traditional examination mode. It need scientific talents of this era who can adapt market, society and enterprise .So education concept of "product market" is changing with the development of higher education development.

4) "Product market" education concept has the foresight of cultivating talents.

"Product marketing" education concept has the foresight of cultivating talents and a new value setting to campus teaching goal and direction.It reflects a future development direction of colleges. The forward-looking education concept of "Product market" will become the thought guide for colleges and indicate the course for teachers' teaching, practice and students' employment.

\section{PRODUCTION MODE}

\section{A. Production principle}

\section{1) Lay a good foundation of basic principle}

Market demands for talents are mainly manifested in operation application which often conceal the basic theoretical knowledge which talents must have. Without solid theoretical knowledge, the technology development of talents application is possible to be constrained. Therefore, in the guidance of "product market" , we need to adhere to the principle of solid basic theory of cultivation and give space for the future development for talents.

\section{2) Market-oriented principle}

Under the "product market" concept, colleges need to make plans according to talents market supply and demand mechanism .If colleges "product" "closed", the consequence will definitely be at a loss about the "sales"after "output".

\section{3) “Students-oriented " principle}

The concept of "product market" is to achieve students-oriented education management. All the work in college should be carried out closely around cultivating students. Students are the "foundation of life"of college development and existing and teachers are the processing technician of the "products". The job of administrators and teachers is to produce "high quality products". For teachers, it's not only the transformation of education idea, but also the role relocation. Teachers must improve themselves in thought, knowledge structure, operation skills, teaching methods and process. Also,it requires to improve themselves in the process of "production" and improve the "processing technology".

4) Quality and after-sales service principle

Higher education, by no means, ends up with the students graduation and getting employed. In fact, students employment is the continuation and extension of higher education. The "reputation"of college"production" comes from market feedback and evaluation. Colleges rely on the competitive edge of "products" to earn the development. Only when colleges attach great important to the quality of"products" ,can they keep up with demand .Also, it's more important to pay attention to after-sales service, in order to know the quality of the 
"products".In this way, can they maintain the relationship between colleges and enterprises, find the defects of "products" and form a good circulation of teaching and scientific research.

\section{B. Production models}

\section{1) Establish product $R \& D$ platform}

Investigations show that in the future there are still competition in the "raw material"-students. There is only one advantage index for the winner-"social competitive comment",namely the leading scientific research level and high quality teaching quality. So the graduates can get the recognition of the society to easily obtain employment. Every college are faced with such a test --if the "product" "luxury" and "with good quality". As a result, colleges must pay attention to the research and development of this special product--students.On one hand, they need to dedicate to study what products the society need and how the quality and quantity of the products can meet the supply-demand change.On the other hand, what the life cycle and characteristics of the products are. Take full account of the social use and achievement time. By establishing research and development platform to make a survey about the market demand and talents prospective forecast, make production standard to get colleges to meet the competitions in advance to prepare for the meeting market challenge.

\section{2) Product manufacturing process re-forger}

In the past, colleges cultivate students were according to the traditional and advantages of school and make it step by step. They lagged behind the market adjustment, so it caused a significant number of students to have trouble finding a job. To change this situation, they must carry on product manufacturing process re-forger. To begin with, make forecast about what kind of students the society need according to research and development platform.Secondly, adjust students cultivation program according to production standard and adjust curriculum .Thirdly, practice while cultivating, cultivate while adjusting. Increase all kinds of social activities while doing students basic theory education.Find the defect during practice.

\section{3) Establish product $R \& D$ platform}

- Establish simulation experiment platform. Campus need market simulation experiment platform more. Students practise actual combat ability through simulation experiment platform.College need accounting simulation laboratory. Student who can make bills and reports can be skilled employee after they work. Manage information management laboratory, computer software development laboratory, hardware maintenance laboratory and so on. Only establishing various simulation experiment platforms which are closely connected with practice can we ensure more value and social adaptability of the products.

- Establish college-enterprise cooperation platform." Product market"concept is to achieve the demand docking between colleges and enterprises. Enterprises need talents and research of college to solve the management problems. While colleges need enterprise to carry on the talent employment and scientific research. In investigation, colleges should seek counterpart enterprises according to the characteristics of their scientific research technology and establish scientific research and training base. Enhance the scientific cooperation between colleges and enterprises and the combination of scientific research and production. The mutual support, mutual penetration, mutual involvement , complementary advantages, resource sharing and mutual benefits are the important way to realize college scientific research industrialization, promote productivity development, speed up scientific research level and enterprise technological progress.

- Set up scientific research platform. Request students to read at least one book on scientific research and write one paper about scientific research for each semester. Each semester, hold one exchange activity about related discipline front theory and practice; Every student organize a scientific research project each semester. Put scientific research into everyday study and make students creative and rational talents.

- Set up self-employment platform. Set up all sorts of interest groups and communities under the guidance of school, cultivate the innovation ability and practical ability of students to manufacture the products which society needs. First, perfect organization. Set up the interest group or community associated with social practice. They are with clear goal, perfect organization and scientific activity plan. Second, carry on the plan strictly. Make good plan and content for each activity and record every activity well. Third, Make good implementation. Each group should make sure five implementations, namely organization implementation, personnel implementation, place implementation, time implementation, couching implementation. Fourth, avoid becoming mere formality. Plan should practical and concrete not let it go. Choose professional counseling teachers to guide on site. Fifth, Enhance supervision. Supervisors in charge of students should check activity timely, correct problems if there are some and ensure the normal activities.

4) Strengthen after-sales service and information feedback research

Talent cultivation under "product market" concept doesn't end with the adaption after graduation, more importantly, it must have the duty to serve and track graduates' quality. The adaption after graduation just mean talents can adapt to enterprise in terms of skills and quality, not meaning the talents have the future of the enterprise. "Product"after-sales service is the best market testing for cultivating talents. Through after-sales service colleges can see the advantages and disadvantages of the talents they cultivate. After-sales service can test the advantages and disadvantages of teacher staff and education methods in market talent mechanism, avoid title assessment affected by emotions and improve the teaching staff and teaching quality .What's important is that after- 
sales service can improve the cooperation of strategic talent and scientific research of colleges and enterprises, improve the credibility and popularity of colleges and enterprises and lay good market foundation for colleges' long-term development.

\section{CONCLUSIONS}

If colleges count on the historical "template", ignoring talents market demand rules, it will inevitably lead to "graduation means unemployed".If this trend continues, it won't cause "campus difficulty" in a short period, but it will surely influence the teaching and scientific research level and future development. The concept of "Product market" is extremely good for colleges teaching and scientific research level and scientific development. It's helpful to definite teaching purpose ,improve teaching enthusiasm, form a scientific teaching evaluation and feedback system and bring vitality for college development.

\section{ACKNOWLEDGMENT}

This work was financially supported by Liaoning Province Education Science "Twelfth Five Year Plan" under Grant (JG15EB068).

\section{REFERENCES}

[1] Wang Shiwei, Du Yiqiang. Well Done the Work of College Headteacher and Create Harmonious Class [J]. Tarim University.2009, 21 (4): 96-99.

[2] Han Chaoying. Analysis on the Epochal Character of the Work of College Head-teacher [J]. Jilin Provincial Institute of Education. 2009, 25 (II) :73-74.

[3] X. Z. Zhe, A. W. Han. The Present Situation, problems, and countermeasures of Higher Engineering Education in China[J]. Shanghai Journal of Educational Evaluation, 2015, (04):21-26.

[4] S. R. Hu, H. Zhao. Practice and Exploration of the Certification of Engineering Education in Electronic Information Engineering Specialty[J]. Journal of Wuhan University, 2012, 2:130-132. Nicole, "Title of paper with only first word capitalized," J. Name Stand. Abbrev., in press.

[5] Shen Guoliang, Exploration of existing problems in project teaching course development[J]. China Adult Education. 2010(11):159-160.

[6] Dong Jiandang, Sun Zhuohui. To maintain the role of instructors in security and stability of college[J]. Science \& Technology Information.2010 (I): 52-53. Electronic Publication: Digital Object Identifiers (DOIs):

[7] YuXiao,KongHanbing. The ability to guide the engineering practice pattern comparison and evaluation [J]. HIGHER EDUCATION OF ENGINEERING, 2011, (3):22-25.

[8] Yin Xiaodong. The main factors affecting the quality of doctoral and postgraduate training study [D]. Southwest University 2014.

[9] Wang xiang, Vocational education "project-specific" teaching model building path and practice effect study [J]. China Adult Education. 2014(11):119-122.

[10] Kang Lijuan, Application of Competency-based Project Teaching in "Business Etiquette" Course [J]. Education and Vocation. 2012(32): 152-153. 